\title{
Uji Daya Adaptasi Varietas Unggul Baru (VUB) Komposit “Varietas Srikandi Andi Depu 1" Di Wilayah Polewali Mandar
}

\author{
Fitriani $^{* *}$, Abd Jamal ${ }^{2}$, Najma $\mathrm{Ali}^{3}$ \\ ${ }^{1,2}$ Program Studi Agroteknologi, Fakultas Ilmu Pertanian, Universitas Al Asyariah Mandar \\ ${ }^{3}$ Program Studi Peternakan, Fakultas Peternakan dan Perikanan, Universitas Sulawesi Barat \\ *Email: ruslanfitriani@gmail.com
}

\begin{abstract}
Penelitian bertujuan untuk mengetahui varietas jagung yang adaptif pada agroekosistem lahan sawah tadah hujan. Metode yang digunakan dalam penelitian ini adalah Rancangan Acak Kelompok (RAK) lengkap Materi genetik VUB Srikandi Depu 1 disandingkan dan ditanam bersama dengan tiga VUB komposist yaitu Provit A1, Sukmaraga, dan Anoman 1, serta dua hibrida Bisi 2 dan P21.. Penyusunan perlakuan adalah V1 = VUB Andi Depu 1., V2 = Varietas Jagung Provit A., V3 = Varietas jagung Komposit Sukamarga., V4 = Varietas Jagung Komposit Anoman, V5 = hibrida Bisi2., dan V6 = Hibrida P21. Parameter yang diamati adalah : Komponen vegetatif tanaman (persentase tanaman tumbuh, tinggi tanaman saat panen) dan Komponen generatif (umur 50\% bunga jantan, umur 50\% bunga betina, tinggi tongkol, panjang tongkol, bobot tongkol, diameter tongkol, jumlah baris/tongkol, jumlah biji/baris, bobot biji kering, kadar air biji dan hasil per petak dan per hektar. Hasil penelitian 1. Perlakuan varietas jagung yang diuji menunjukkan pengaruh yang nyata $(\mathrm{P}<0,05)$ terhadap sebagian besar parameter tanaman yang diamati, sedangkan presentase tanaman tumbuh tidak berbeda nyata. 2. Varietas hibrida dan varietas unggul menunjukkan komponen pertumbuhan yang lebih baik sedangkan komponen hasil yang tinggi ditunjukkan oleh varietas Hibrida dan varietas unggul 3. Varietas Unggul Baru (VUB) Andi Depu 1 mampu beradaptasi dengan baik dengan lingkungan pada lahan sawah tadah hujan di Kabupaten Polewali Mandar Propinsi Sulawesi Barat. 4. hektar Hasil yang diperoleh berturut-turut adalah varietas Propit (8,52 t.ha -1),begitu juga dengan varietas VUB Andi depu 1 (7,96 t. ha -1) dan varietas sukamarga (5,93t.ha-1). Varietas Anoman menghasilkan $(5,55$ t.ha -1$)$, lebih tinggi dari rata-rata hasil dalamdiskripsi varietas $(5,25$ t.ha -1$)$. Bisi $2(4,77$ t.ha -1$)$ sesuai dengan rata-rata hasil sedangkanHibrida P21 (4,30 t.ha-1) produktivitasnya lebih rendah dibandingkan dengan varietas lainnya.
\end{abstract}

Keywords : Varietas; Adaptasi; Produksi; Polewali Mandar

\section{Pendahuluan}

Jagung (Zea mayz L.) merupakan komoditas yang memiliki peranan penting dalam perekonomian nasional dan diharapkan dapat menjadi sumber devisa melalui pengembangan pasar ekspor. Ditinjau dari aspek pengusahaan dan penggunaan hasilnya, jagung termasuk komoditas palawija utama di Indonesia, baik sebagai bahan pangan maupun pakan (1). Kebutuhan jagung Ringkasan penelitian tidak lebih dari 500 kata yang berisi latar belakang penelitian, tujuan dan tahapan metode penelitian, luaran yang ditargetkan, serta uraian TKT penelitian yang diusulkan. Kata kunci maksimal 5 kata Latar belakang penelitian tidak lebih dari 500 kata yang berisi latar belakang dan permasalahan yang akan diteliti, tujuan khusus, dan urgensi penelitian. Pada bagian ini perlu dijelaskan uraian tentang spesifikasi khusus terkait dengan skema. untuk pangan, pakan ternak, dan bahan baku industri terus meningkat. Hal ini merupakan tantangan dalam penyediaan jagung secara berkesinambungan. Dalam industri makanan, minuman dan pakan ternak, jagung memiliki komposisi terbesar untuk pakan, bahan baku industri minyak makan, pati dan minuman. Penelitian menunjukkan jagung dapat digunakan sebagai bahan pangan alternatif, baik sebagai bahan setengah jadi maupun bahan jadi (2). Komoditas pertanian yang diprioritaskan pengembangannya pada suatu wilayah sudah diusahakan oleh masyarakat setempat, yang mampu bersaing dengan skala ekonomi tertentu (3) Selama periode kabinet kerja,
Indonesia telah berhasil menghentikan import jagung yang selama ini mencapai $1,0-1,5$ juta ton per tahun. Salah satu faktor pendukungnya adalah penerapan VUB (Varietas Unggul Baru) nasional, baik hibrida mapun komposit. Sulbar sebagai propensi termuda di Indonesia perlu mendukung kebijakan pemerintah dalam hal peningkatan produksi, baik jagung peruntukan pakan maupun untuk konsumsi pangan.

Agroekosistem Sulbar yang bervariasi memerlukan VUB yang adaptif dengan target produksi setara tingkat nasional. Wilayah Sulbar dari dataran rendah zona tropis yang sejajar permukaan laut sampai ketinggian diatas 900 m dpl.. Srikandi Depu 1 dirilis sebagai VUB nasional tgl 22 Mei 20017 sesuai surat keputusan Mentan: 337/Kpts/TP.040/5/2017 (Anonimous, 2017). Varietas ini dirakit dari populasi POP66C0.QPM.TLYQ berasal dari CIMMYT Mexico. (Yasin et al., 2014). Materi genetik POP66 : Population 66, C0 : Status/Daur : C0, QPM : Quality Protein Maize, TLYQ Tropical Late Yellow QPM telah mengalami perbaikan genetik dengan perbaikan dalam populasi Intra Population Improveent (Irma Yuliana, 2011). Benih dimurnikan, digandakan dan UML dilaksanakan oleh Balitsereal Maros dalam MT 2014. Produksi Srikandi Depu 1 pada akhirnya diharapkan dapat meningkatkan pendapatan petani serta turut andil dalam penyebaran dan mempertahankan swasembada jagung nasional. Sebagai langkah awal, varietas ini perlu dilakukan pengembangan dan uji adaptasi pada lahan sentra jagung dengan agroekosistem yang berbeda. Pemberian nama 
Srikandi Depu 1, akan mengingatkan petani sebagai penghargaan atas pahlawan Mandar ANDI DEPU, dalam melawan penjajah Belanda dan puncaknya saat panglima Westerling mengexekusi rakyat mandar 40.000 jiwa. Nama Srikandi Depu 1 diharapkan agar petani dapat menanam varietas ini serta tanda penghargaan bagi pahlawan Mandar.

Tujuan penelitian ini adalah untuk mengetahui varietas jagung yang adaptif pada agroekosistem lahan sawah tadah hujan dan dapat dijadikan sebagai referensi bagi petani di Polewali Mandar.

\section{Metodologi}

Penelitian ini dilaksanakan di Desa Panyampa Kecamatan Campalagian Kabupaten Polewali Mandar provinsi Sulawesi Barat. Materi genetik VUB Srikandi Depu 1 disandingkan dan ditanam bersama dengan tiga VUB komposist yaitu Provit A1, Sukmaraga, dan Anoman 1, serta dua hibrida Bisi 2 dan P21.. Penyusunan perlakuan adalah V1 = VUB Andi Depu 1., V2 = Varietas Jagung Provit A., V3 = Varietas jagung Komposit Sukamarga., V4 = Varietas Jagung Komposit Anoman, V5 = hibrida Bisi2., dan V6 = Hibrida P21 Dikemukakan oleh (Hallauer dan Miranda, 1988) bahwa pada lingkungan optimal maupun tercekam produktivitas OPV dapat menyamai hibrida Metode yang digunakan dalam Analisis data adalah Rancangan Acak Lengkap (RAK), terhadap penggunaan materi genetik, (Gomez and Gomez. 1984). Keenam materi genetik ditanam dengan jarak $75 \times 25 \mathrm{~cm}$, satu tanaman per rumpun. Persiapan lahan dilakukan dengan membajak dan digaru sampai lahan siap tanam. Dipupuk Urea-Ponska (150-200) kg/ha ditambah pupuk kandang kambing 1 ton. Perlakuan benih akan diberikan seed treatment yakni pestisid a b.a. matalaxy sesuai anjuran, furadan 3G mencegah ulat grayak, serta penyiangan dan pembumbunan dilakukan sesuai kebutuhan tanaman. Data yang dikumpulkan adalah:

a. Komponen vegetatif tanaman (persentase tanaman tumbuh, tinggi tanaman saat panen)

b. Komponen generatif (umur $50 \%$ bunga jantan, umur $50 \%$ bunga betina, tinggi tongkol, panjang tongkol, bobot tongkol, diameter tongkol, jumlah baris/tongkol, jumlah biji/baris, bobot biji kering, kadar air biji dan hasil per petak dan per hektar.

\section{Hasil}

Hasil Tinggi Tanaman Hasil pengamatan tinggi tanaman dan sidik ragamnya disajikan pada tabel lampiran 1a dan 1b. Analisa sidik ragamnya menunjukkan bahwa perlakuan beberapa varietas unggul jagung hibrida berbeda sangat nyata terhadap tinggi tanaman. Tabel 1. Rata-rata Tinggi Tanaman (cm) Jagung Pada Berbagai Jenis Varietas jagung.

\begin{tabular}{lcc} 
VARIETAS & Tinggi Tanaman & Tinggi Tongkol \\
\hline VUB Andi Depu (V1) & $297,33^{\mathrm{c}}$ & $136,00^{\text {th }}$ \\
Provit A (V2) & $287,22^{\mathrm{bc}}$ & $133,33^{\text {th }}$ \\
Sukamarga (V3) & $279,56^{\mathrm{b}}$ & $118,78^{\text {th }}$ \\
Anoman (V4) & $284,11^{\mathrm{b}}$ & $131,56^{\text {th }}$ \\
Bisi 2 (V5) & $281,33^{\mathrm{b}}$ & $118,78^{\text {th }}$ \\
Hibrida P21 (V6) & $226,33^{\mathrm{a}}$ & $116,55^{\text {th }}$
\end{tabular}

Keterangan: Huruf yang sama pada kolom yang sama berarti berbeda tidak nyata pada taraf 5 persen

Hasil Uji BNT pada Tabel 1 memperlihatkan bahwa Varietas VUB Andi Depu 1 (V1) memberikan rata-rata tinggi tanaman terbaik yaitu $297,33 \mathrm{~cm}$ dan berbeda sangat nyata dengan varietas Hibrida P21, Bisi2, dan Anoman Tetapi tidak berbeda nyata dengan varietas provit A . Sedangkan rata rata tinggi tanaman yang terendah yaitu varietas hibrida P21 (V6) dengan rata rata tinggi tanaman $226,33 \mathrm{~cm}$. Dari hasil ini, ternyata bahwa tinggi tanaman varietas-varietas yang diuji lebih tinggi dari hasil diskripsi yang digunakan. Hal ini membuktikan bahwa pertumbuhan tinggi tanaman untuk semua varietas mulai awal pertumbuhan sangat cepat sampai pada umur 54 hari setelah tanam (hst) dan mengalami penurunan hingga konstan pada umur 63 hst sampai panen. Tinggi tanaman sangat menentukan adaptasi dari galur/varietas tanaman pada lingkungan dimana tanaman tumbuh. Untuk parameter tinggi tongkol tidak menunjukan pengaruh nyata tetapi jagung varietas Andi depu 1 menunjuk kan angka tertinggi $(136,00 \mathrm{~cm})$ dibanding varietas lainnya, sedangkan varietas Hibrida P21 memiliki tinggi tongkol yang terendah dibandingkan dengan varietas lainnya (Tabel 1). Keuntungan dari tanaman yang memiliki letak tongkol tinggi adalah aman dari serangan hama.

\section{Komponen Generatif}

Komponen hasil yang diamati umur $50 \%$ bunga jantan, umur $50 \%$ bunga betina

Tabel 1. Umur 50\% bunga jantan dan $50 \%$ bunga betina berbagai jenis varietas jagung

\begin{tabular}{lcc} 
VARIETAS & Bunga Jantan & Bunga Betina \\
\hline VuB Andi Depu (V1) & $50,67^{\mathrm{a}}$ & $54,33^{\mathrm{a}}$ \\
Provit A (V2) & $47,67^{\mathrm{a}}$ & $54,22^{\mathrm{a}}$ \\
Sukamarga (V3) & $46,33^{\mathrm{a}}$ & $51,00^{\mathrm{a}}$ \\
Anoman (V4) & $45,33^{\mathrm{a}}$ & $46,78^{\mathrm{a}}$ \\
Bisi 2 (V5) & $46,33^{\mathrm{a}}$ & $49,67^{\mathrm{a}}$ \\
Hibrida P21 (V6) & $38,33^{\mathrm{a}}$ & $46,33^{\mathrm{a}}$ \\
\hline Keterangan: & Huruf yang sama pada kolom yang sama berarti berbeda tidak nyata pada taraf 5 persen
\end{tabular}

Analisa menunjukkan bahwa perlakuan beberapa varietas jagung tidak berbeda nyata terhadap umur berbunga jantan. Pada tabel 1 diatas menunjukkan bahwa perlakuan varietas VUB Andi Depu memberikan hasil tertinggi terhadap umur berbunga jantan (50,67 hari), 
sedangkan umur berbunga jantan terendah diperoleh pada varietas yaitu varietas Hibrida P21 $(38,33)$ hari. Hasil pengamatan umur berbunga jantan pada table 1 menunjukkan bahwa perlakuan varietas Andi Depu paling lambat berbunga hal ini diduga disebabkan karena karakter calon varietas jagung yang berbeda, terjadi kekeringan pada saat pembungaan sehingga mempengaruhi penyerbukan dan akan mempengaruhi pembentukan biji, di mana jika kondisi kering bunga jantan tidak akan mekar, ini sejalan dengan pendapat Takdir (2007), yang menyatakan kekeringan mempengaruhi mekarnya bunga jantan. Pada parameter $50 \%$ bunga betina dari analisa yang dilakuka menunjukkan bahwa perlakuan beberapa varietas jagung tidak berbeda nyata terhadap umur berbunga betina.

Pada table 1 diatas menunjukkan bahwa perlakuan varietas Andi Depu memberikan hasil tertinggi terhadap umur berbunga betina (54,33 hari), sedangkan umur berbunga betina terendah diperoleh pada varietas yaitu varietas Hibrida P21 (46,33) hari. Jadi varietas Andi Depu paling lambat berbunga dan varietas Hibrida P21 paling cepat berbunga.

Bunga betina muncul dari axillary apices tajuk, bunga betina muncul setelah 3 hari munculnya bunga jantang keadaan stress karena kekurangan air, keluarnya rambut tongkol kemungkinan tertunda, sedangkan keluarnya malai tidak terpengaruh. Interval antara keluarnya bunga betina dan bunga jantan (anthesis silking interval, ASI) adalah hal yang sangat penting. ASI yang kecil menunjukkan terdapat sinkronisasi pembungaan, yang berarti peluang terjadinya penyerbukan sempurna sangat besar. Baneti (1992), menyatakan kekeringan dapat menyebabkan tanaman akan mengalami peningkatan ASI (Anthesis silking interval), sehingga penyerbukan tidak sinkron dan pembentukan biji yang tidak optimal atau bahkan sama sekali tidak ada biji yang terbentuk karena adanya reduksi hasil fotosintesis.

Tinggi tongkol, panjang tongkol, bobot tongkol, diameter tongkol, jumlah baris/tongkol, jumlah biji/baris, bobot biji kering, kadar air biji dan hasil per petak dan per hektar menunjukan perbedaan antara varietas yang diuji Hasil analisis menunjukkan varietas Provit A memiliki diameter tongkol terbesar $(7,67 \mathrm{~mm})$, dan tidak berbeda dengan varietas VUB Andi Depu $1(7,17 \mathrm{~mm})$, tetapi berbeda dengan varietas Sukamarga $(6,33 \mathrm{~mm})$, varietas Anoman, Varietas hibrida P21 dan varietas Bisi 2 yang menunjukan diameter tongkol terkecil $(5,30 \mathrm{~mm})$. Pada parameter panjang tongkol varietas Andi depu 1 menunjukkan panjang tongkol terpanjang $(19,94 \mathrm{~cm})$ dan tidak berbeda dengan varietas Propit $\mathrm{A}(18,61 \mathrm{~cm})$ dan varietas Sukamarga $(19,72 \mathrm{~cm})$. Sebaliknya varietas Hibrida P21 menunjukan panjang tongkol terpendek $(5,87$ $\mathrm{cm})$. Panjang tongkol dan diameter tongkol berkaitan erat dengan rendeman hasil suatu varietas. Jika panjang tongkol suatu varietas lebih dari varietas yang lain, maka varietas tersebut berpeluang memiliki hasil yang lebih tinggi dari varietas lain (Welsh, 1991).

Robi'in, dalam Irma 2009 Niviana dan Iskandar Ishaq, 2011). Panjang tongkol isi menunjukkan kepadatan biji yang terbentuk dan erat kaitannya dengan jumlah biji pertongkol dari varietas yang diuji. Untuk jumlah baris/tongkol menunjukan semua varietas tidak berbeda nyata tetapi varietas Anoman menunjukan jumlah baris per tongkol lebih banyak $(13,56)$ dibandingkan dengan varietas lainnya . Jumlah biji dalam satu baris jagung, terbanyak ditunjukkan oleh Sukamarga $(38,33)$, diikuti varietas Anoman (37,33), varietas Andi Depu $1(36,89)$, sedangkan varietas Hibrida P21 menunjukkan jumlah biji per baris lebih sedikit dibandingkab dengan varietas lainnya.

Tabel 3. Diameter tongkol, Panjang tongkol dan Jumlah Baris Tongkol dan Jumlah biji baris dari berbagai jenis varietas jagung

\begin{tabular}{lcccc} 
VARIETAS & $\begin{array}{c}\text { Diameter } \\
\text { Tongkol }\end{array}$ & $\begin{array}{l}\text { Panjang } \\
\text { Tongkol }\end{array}$ & $\begin{array}{l}\text { Jumlah } \\
\text { Baris per } \\
\text { Tongkol }\end{array}$ & $\begin{array}{l}\text { Jumlah } \\
\text { Biji per } \\
\text { baris }\end{array}$ \\
\hline VUB Andi Depu (V1) & $7,17^{\mathrm{c}}$ & $19,94^{\mathrm{c}}$ & $13,00^{\text {th }}$ & $36,89^{\mathrm{c}}$ \\
Provit A (V2) & $7,67^{\mathrm{c}}$ & $18,61^{\mathrm{bc}}$ & $13,11^{\text {th }}$ & $35,00^{\mathrm{c}}$ \\
Sukamarga (V3) & $6,33^{\mathrm{ab}}$ & $19,72^{\mathrm{c}}$ & $13,00^{\text {tn }}$ & $38,33^{\mathrm{bc}}$ \\
Anoman (V4) & $6,00^{\mathrm{ab}}$ & $18,72^{\mathrm{bc}}$ & $13,56^{\mathrm{tn}}$ & $37,33^{\mathrm{bc}}$ \\
Bisi 2 (V5) & $5,30^{\mathrm{ab}}$ & $16,67^{\mathrm{ab}}$ & $12,56^{\text {tn }}$ & $34,89^{\mathrm{ab}}$ \\
Hibrida P21 (V6) & $5,87^{\mathrm{a}}$ & $15,83^{\mathrm{a}}$ & $12,11^{\text {tn }}$ & $32,34^{\mathrm{a}}$
\end{tabular}

Keterangan:
Huruf yang sama pada kolom yang sama berarti berbeda tidak nyata pada taraf 5 persen

Hasil analisis menunjukan tidak ada perbedaan antara varietas yang diuji, kecuali varietas Hibrida P21 berbeda nyata. Bobot tongkol dari varietas yang diuji adalah tertinggi ditunjukkan oleh varietas Profit A $(197,5)$, diikuti oleh varietas sukamarga $(194,57)$, Bisi 2 (190,22) Andi depu (181,22), Anoman (176,31), dan terendah adalah varietas Hibrida $(175,20)$. Hasil Analisa sidik ragam yang dilakukan menunjukkan tidak ada perbedaan antara tujuh varietas yang diuji. Berat tongkol merupakan salah satu komponen hasil selain panjang tongkol dan diameter tongkol yang mempengaruhi rendeman hasil tanaman jagung. Umumnya, berat tongkol berkorelasi positif dengan hasil tanaman jagung.

Tabel 4. Berat tongkol, Berat 1000 biji dan Hasil (t/ha) dari berbagai varietas jagung

\begin{tabular}{lccccc} 
VARIETAS & Bobot Tongkol & $\begin{array}{c}\text { Bobot } \\
\text { Kering Biji } \\
(\mathrm{Kg})\end{array}$ & $\begin{array}{c}\text { Kadar Air } \\
(\%)\end{array}$ & $\begin{array}{c}\text { Hasil per } \\
\text { petak }\end{array}$ & $\begin{array}{c}\text { Hasil /Ha } \\
\text { (Ton/Ha) }\end{array}$ \\
\hline VuB Andi Depu (V1) & $181.22^{\mathrm{a}}$ & $7,17^{\mathrm{a}}$ & $13,00^{\mathrm{a}}$ & $7,16^{\mathrm{a}}$ & $7,96^{\mathrm{a}}$ \\
Provit A (V2) & $197.50^{\mathrm{a}}$ & $7,67^{\mathrm{a}}$ & $13,11^{\mathrm{a}}$ & $7,67^{\mathrm{a}}$ & $8,52^{\mathrm{a}}$ \\
Sukamarga (V3) & $194.57^{\mathrm{a}}$ & $5,33^{\mathrm{a}}$ & $13,00^{\mathrm{a}}$ & $5,34^{\mathrm{a}}$ & $5,93^{\mathrm{a}}$ \\
Anoman (V4) & $176.31^{\mathrm{a}}$ & $5,00^{\mathrm{a}}$ & $13,56^{\mathrm{a}}$ & $5,00^{\mathrm{a}}$ & $5,55^{\mathrm{a}}$ \\
Bisi 2 (V5) & $190.22^{\mathrm{a}}$ & $4,30^{\mathrm{a}}$ & $12,56^{\mathrm{a}}$ & $4,29^{\mathrm{a}}$ & $4,77^{\mathrm{a}}$ \\
Hibrida P21 (V6) & $175.20^{\mathrm{a}}$ & $3,87^{\mathrm{a}}$ & $12,11^{\mathrm{a}}$ & $3,87^{\mathrm{a}}$ & $4,30^{\mathrm{a}}$ \\
\hline Keterangan: & & & & &
\end{tabular}

Huruf yang sama pada kolom yang sama berarti berbeda tidak nyata pada taraf 5 persen

Terhadap parameter kering biji Propit A memberikan bobot terberat $(7,67 \mathrm{~kg})$ per petak dan tidak berbeda nyata dengan varietas lainnya, sedangkan varietas Hibrida P21 memberikan bobot biji kering per petak paling ringan yaitu $3,87 \mathrm{~kg}$. Kadar air biji saat pengukuran berada pada kering panen (12 - 14\%), sehingga data bobot kering biji jagung yang diperoleh, lebih tinggi. Hasil analisis yang dilakukan menunjukkan bahwa varietas yang diuji tidak terdapat perbedaan yang nyata antar varietas. Pada parameter hasil perpetak dari 
analisis yang dilakukan tidak menunjukan hasil yang berbeda nyata, tetapi varietas Provit A menunjukkan hasil yang tertinggi dibandingkan dengan varietas lainnya demikian juga pada parameter hasil per hektar Hasil yang diperoleh berturut-turut adalah varietas Propit (8,52 t.ha -1), begitu juga dengan varietas VUB Andi depu 1 (7,96 t. ha -1) dan varietas sukamarga (5,93 t.ha-1 ). Varietas Anoman menghasilkan (5,55 t.ha -1 ), lebih tinggi dari rata-rata hasil dalam diskripsi varietas $(5,25$ t.ha -1$)$. Bisi 2 (4,77 t.ha -1$)$ sesuai dengan ratarata hasil sedangkan Hibrida P21 (4,30 t.ha-1) produktivitasnya lebih rendah dibandingkan dengan varietas lainnya.

\section{Kesimpulan}

Berdasarkan hasil penelitian dan pembahasan yang dilakukan, maka dapat ditarik beberapa kesimpulan, diantaranya:

a. Perlakuan varietas jagung yang diuji menunjukkan pengaruh yang nyata $(\mathrm{P}<0,05)$ terhadap sebagian besar parameter tanaman yang diamati, sedangkan presentase tanaman tumbuh tidak berbeda nyata.

b. Varietas hibrida dan varietas unggul menunjukkan komponen pertumbuhan yang lebih baik sedangkan komponen hasil yang tinggi ditunjukkan oleh varietas Hibrida dan varietas unggul 1 Varietas Unggul Baru (VUB) Andi Depu 1 mampu beradaptasi dengan baik dengan lingkungan pada lahan di Kabupaten Polewali Mandar Propinsi Sulawesi Barat. 4. Hasil yang diperoleh berturut-turut adalah varietas Propit $(8,52$ t.ha -1), begitu juga dengan varietas VUB Andi depu 1 (7,96 t. ha -1) dan varietas sukamarga (5,93 t.ha-1 ). Varietas Anoman menghasilkan (5,55 t.ha -1), lebih tinggi dari rata-rata hasil dalam diskripsi varietas $(5,25$ t.ha - $)$. Bisi 2 (4,77 t.ha -1) sesuai dengan ratarata hasil sedangkan Hibrida P21 (4,30 t.ha-1) produktivitasnya lebih rendah dibandingkan dengan varietas lainnya.

\section{Ucapan Terima Kasih}

Ucapan terima kasih Kepada Menteri Pendidikan dan Kebudayaan, LLD Dikti Wilayah IX atas batuan dana sehingga penelitian ini dapat dilaksanakan.

\section{Daftar Pustaka}

Anonimous, 2017. Keputusan Menteri Pertanian Republik Indonesia. Pelepasan Galur Jagung Bersari Bebas Q.COM.C0(SK2) sebagai Varietas Unggul dengan Nama SRIKANDI DEPU 1. Kementan. Jakarta.

Baneti P, ME Wesgate 1992. Water deficit affects receptivity of maize silks. Crop Sci. 33(2):279- 282.

Gomez. K. A., and A. A. Gomez., 1984. Statistical procedures for agricultural research. $2^{\text {nd }}$. An IRRI Book. John Wiley \& Sons. Singapore. p. 441

Hallauer. A. R., and J. B. Miranda. Fo. 1988. Quantitative genetics in maize breeding. 2nd. Iowa State University Press/Amess. p. 1592nd. Iowa State University Press/Amess. p. 159.

Irma Noviana dan Iskandar Ishaq. 2011. Karakter hasil galur dan varietas jagung pada MK II di Jawa Barat Dalam Prosiding Seminar Nasional Pengkajian dan Diseminasi Inovasi Pertanian Mendukung Program Strategis Kementrian Pertanian. Cisarua, 9-11 Desember 2010. Hlm: 1548- 1552.

Takdir A.,. 2007. Pembentukan varietas jagung hibrida, hal 74-95. Dalam Jagung. Pusat Penelitian dan Pengembangan Tanaman Pangan, Departemen Pertanian.

Yasin HG. M, Sumarno, Amin Nur, 2014. Perakitan Varietas Unggul Jagung Fungsional. IAARD PRES Pusat Penelitian dan Pengembangan Tanaman Pangan. Badan Penelitian dan Pengembangan Tanaman Pangan. Jakarta. p. 51.

Welsh , R. 1991. Dasar-dasar Genetika dan Pemulian Tanaman. Terjemahan Mogea JP. Erlangga Jakarta. 